\title{
Potential influence of wildfire in modulating climate-induced forest redistribution in a central Rocky Mountain landscape
}

\author{
John L. Campbell ${ }^{1 *}$ and Douglas J. Shinneman ${ }^{2}$
}

\begin{abstract}
Introduction: Climate change is expected to impose significant tension on the geographic distribution of tree species. Yet, tree species range shifts may be delayed by their long life spans, capacity to withstand long periods of physiological stress, and dispersal limitations. Wildfire could theoretically break this biological inertia by killing forest canopies and facilitating species redistribution under changing climate. We investigated the capacity of wildfire to modulate climate-induced tree redistribution across a montane landscape in the central Rocky Mountains under three climate scenarios (contemporary and two warmer future climates) and three wildfire scenarios (representing historical, suppressed, and future fire regimes).
\end{abstract}

Methods: Distributions of four common tree species were projected over 90 years by pairing a climate niche model with a forest landscape simulation model that simulates species dispersal, establishment, and mortality under alternative disturbance regimes and climate scenarios.

Results: Three species (Douglas-fir, lodgepole pine, subalpine fir) declined in abundance over time, due to climate-driven contraction in area suitable for establishment, while one species (ponderosa pine) was unable to exploit climate-driven expansion of area suitable for establishment. Increased fire frequency accelerated declines in area occupied by Douglas-fir, lodgepole pine, and subalpine fir, and it maintained local abundance but not range expansion of ponderosa pine.

Conclusions: Wildfire may play a larger role in eliminating these conifer species along trailing edges of their distributions than facilitating establishment along leading edges, in part due to dispersal limitations and interspecific competition, and future populations may increasingly depend on persistence in locations unfavorable for their establishment.

Keywords: Forest disturbance, Wildfire, Climate change, Central Rocky Mountains, Climate niche, Species migration, Species distribution

\section{Introduction}

The spatial distributions of many tree species, as well as the communities they collectively comprise, have been largely explained by climate variables involving the seasonality and magnitude of air temperature and precipitation (Woodward 1987; Woodward and McKee 1999; Rehfeldt et al. 2006). Long-standing concepts of species niche space (Hutchinson 1957; Pearson and Dawson

\footnotetext{
* Correspondence: john.campbell@oregonstate.edu

'Department of Forest Ecosystems and Society, Oregon State University, Corvallis, OR, USA

Full list of author information is available at the end of the article
}

2003) have led to the development of empirically defined bioclimatic envelope models and closely related species distribution models (hereafter, collectively "climate niche models") that can estimate potential plant geographic distributions under both current and future climates (Iverson and Prasad 1998; Bakkenes et al. 2002; Bachelet et al. 2005; Lenihan et al. 2008; Rehfeldt et al. 2012). However, the degree to which plant species can actually realize geographic shifts into favorable climate space is complicated by limitations of dispersal (Neilson et al. 2005; Franklin 2013; Snell 2014), environmental stressors that result in survival thresholds not apparent in current 
species distributions (McKenzie et al. 2009), competition in novel climate space (Neilson et al. 2005; Rehfeldt et al. 2012), and disturbance patterns, which may also be altered by global climate change (Bachelet et al. 2005; Moser et al. 2010; Johnstone et al. 2010; Littell et al. 2010; Loehman et al. 2010).

To better describe plant migration in the face of contemporary climate change, potential plant distribution models are now being paired with a variety of other landscape models in order to consider key processes that may alter the pace and direction of range shifts, including competition, reproduction, and dispersal (Scheller and Mladenoff 2008; Corlett and Westcott 2013; Iverson and McKenzie 2013); growth and production (Boisvenue and Running 2006, 2010) and disturbance events (Conlisk et al. 2012, 2013; Crimmins et al. 2014; Keane et al. 2013; Halofsky et al. 2013; Vanderwel and Purves 2014). While imperfect, such paring of empirical distribution models with landscape process models is beginning to provide a clearer picture of how plants, and the terrestrial ecosystems they define, may move in response to changing climate and disturbance regimes.

The central Rocky Mountains of North America exemplify the combined influence of climate change and disturbance patterns on tree species migration potential. Within this mostly forested region, topography and elevation create steep gradients of temperature and precipitation, over which major tree species are predictably stratified (Daubenmire 1956; Rehfeldt et al. 2008). Human-induced climate change over recent decades has already been implicated in the distributional contraction of some Rocky Mountain tree species (Michaelian et al. 2011; Gitlin et al. 2006; Shaw et al. 2005; Bell et al. 2014a), and a consensus of global circulation models predict further increases in air temperatures and decreases in plant available moisture during the growing season throughout the region (Boisvenue and Running, 2010). However, as in many forested landscapes, rapid tree redistribution imposed by climate change in the Rocky Mountains is potentially resisted via biological inertia, particularly due to long life spans of many tree species and the capacity of deep-rooted, mature individuals to withstand long periods of physiological stress (Moser et al. 2010; Johnstone et al. 2010; Littell et al. 2010; Halofsky et al. 2013). By killing forest canopies, disturbance events such as wildfire can theoretically break this inertia, both by eliminating populations that persist in climatically unfavorable locations and by facilitating establishment of species into newly favorable locations (Neilson et al. 2005; McKenzie et al. 2009, Kuparinen et al. 2010). Yet, it is unclear how shorter fire rotations and greater area burned under climate change will affect species dispersal and establishment opportunities.
Our research goal was to evaluate the capacity of wildfire to modulate the response of forest species to climate change across a climatically diverse landscape in the central Rocky Mountains of North America, where both climate and fire regimes are expected to change dramatically over the next century (Flannigan et al. 2000; Westerling et al. 2006; Barbero et al. 2015). We used a combination of empirical and simulation modeling to explore the following:

1. How might future climate change affect the geographic distribution of favorable climate niche space for regionally important tree species?

2. How will alternative fire regimes and climate scenarios affect the ability of tree species to keep pace with redistribution of favorable sites?

3. How does the pace of redistribution influence the suitability of landscape locations occupied by each tree species?

To address these questions, we used non-parametric multiplicative regression to develop provisional climate niche models for nine regionally dominant tree species and two shrub functional types, and coupled output from these models with a stochastic forest landscape model that simulates interactions between forest disturbance, dispersal, establishment, competition, growth, and mortality. The coupled models were used to simulate change in species distributions under three different 90-year climate scenarios (current conditions, moderate warming, and more severe warming and drying) and three different wildfire scenarios (long, medium, and short rotation fire regimes, nominally representing suppressed, historical, and future fire regimes, respectively). We specifically assessed the projected future redistribution of four of the most dominant and well-distributed tree species in the region (Douglas-fir, lodgepole pine, ponderosa pine, and subalpine fir) to determine how fire might influence shifts in species ranges under climate change.

\section{Methods}

\section{The study area and forest disturbance history}

The study area includes $\sim 17,000 \mathrm{~km}^{2}$ of mountainous terrain in the southern Idaho Batholith (Fig. 1). Elevations range from $\sim 900$ to $3600 \mathrm{~m}$, with low elevations characterized by hot summers and cool winters and high elevations characterized by short growing seasons and cold winters. Precipitation ranges from 220 to $1440 \mathrm{~mm}$ annually, most of it arriving as snow, especially at higher elevations. Natural plant communities are characteristic of the central Rocky Mountains and include the following: (1) semi-arid shrub-bunchgrass communities (shrubs dominated by Artemisia tridentata or Purshia tridentata); 


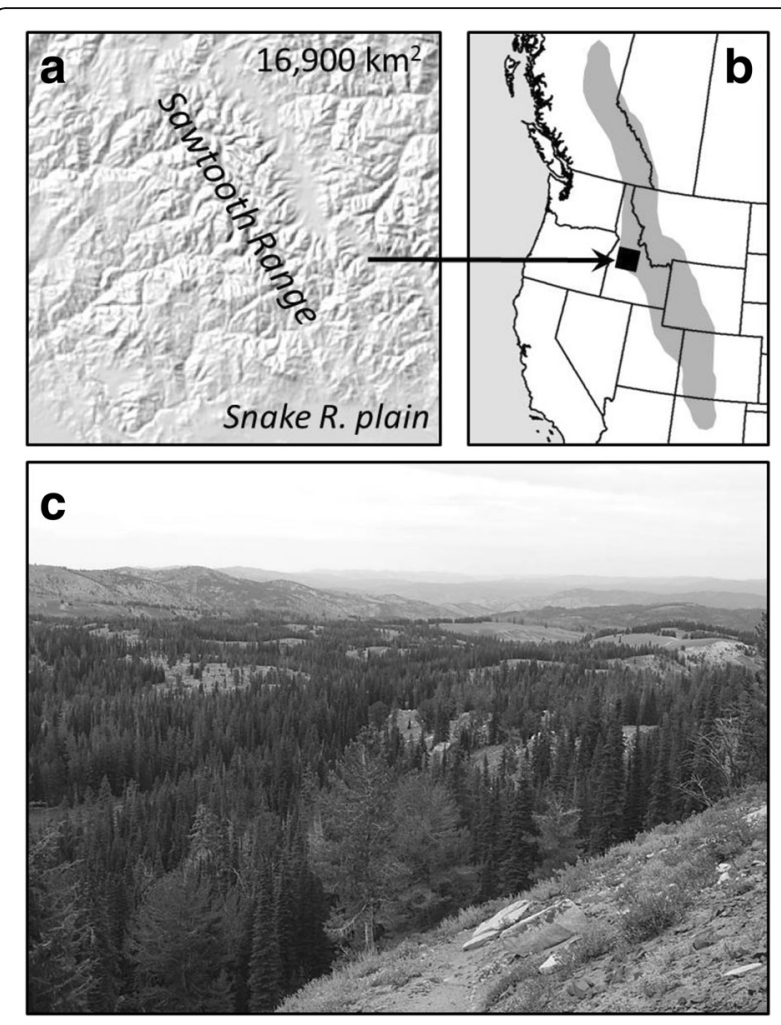

Fig. 1 Study area. a Geographic features of our $130 \times 130 \mathrm{~km}$ study in ID, USA. b Location of our study area in relation to the Rocky Mountains (shaded area), in western North America. c Representative vegetation includes rangelands at lower elevations and mixed conifer forest at higher elevations

(2) montane forests of ponderosa pine (Pinus ponderosa) and Douglas-fir (Pseudotsuga menziesii); (3) upper montane and subalpine forests primarily dominated by lodgepole pine (P. contorta), Engelmann spruce (Picea engelmannii), and subalpine fir (Abies lasiocarpa); (4) mountain shrublands (may include species of Acer, Artemisia, Ceanothus, Juniperus, Prunus, Ribes, Rosa, Rubus, Symphoricarpos, Vaccinium, and others); and (5) alpine meadow. Most land is publically owned and managed for natural resources and outdoor recreation.

Historically, fire has been a key disturbance agent, shaping the distribution, composition, and stand-age structures of these forest communities (Crane and Fisher 1986, Heyerdahl et al. 2008). The mean annual area burned by wildfire in the study area has grown substantially in recent decades, likely driven by climate variability, non-native species, and land-use effects (Morgan et al. 2008; Abatzoglou and Kolden 2011). Systematically mapped fires $>400$ ha from the Monitoring Trends in Burn Severity (MTBS) project (Eidenshink et al. 2007) indicate that $41 \%(683,194$ ha) of our study area burned over a recent 30-year period (1984-2013). In contrast, historical fire records indicate that only $\sim 4 \%(\sim 67,000 \mathrm{ha})$ burned during the previous 50 years (Gibson and Morgan 2009), although earlier data likely under-represent actual area burned due to inconsistent mapping and record keeping (Gibson 2006). Historical fire regimes in the region can be broadly characterized as ranging from relatively infrequent, stand-replacing fire in high-elevation forests and some sagebrush communities, to relatively frequent low- to mixed-severity fire in lower elevation forests (Heyerdahl et al. 2008). However, variability in climate and periodic widespread mortality from forest pathogens also influenced forest conditions and fire regimes over time (Pierce et al. 2004, Brunelle et al. 2008, Baker 2009, Whitlock et al. 2011).

\section{General modeling approach}

Simulating the redistribution of tree species under alternative climate and fire scenarios involved three main steps. First, we used non-parametric multiplicative regression to develop empirical climate niche models for each of several tree species and two shrub functional types. Second, we used future climate projections (for the years 2030, 2060, and 2090) from two alternative emission scenarios to project future distributions of each species' climate niche. Third, landscape vegetation dynamics were simulated over a 90 -year period using a forest landscape simulation model (FLSM), "LANDIS-II," under the two future climate scenarios and three alternative fire regimes. Species probability of occurrence values derived from the climate niche models (in step two) were used to represent spatially explicit estimates of species establishment probabilities (SEPs) under current and future climate within the landscape simulation model. This approach allowed us to compare differences among projected climate niche distributions and simulated changes in species redistribution under alternative climate scenarios and fire regimes, as constrained by species dispersal, growth, mortality, and competitive interactions (described in detail below).

\section{Development of the climate niche models}

We used non-parametric multiplicative regression (NPMR) in HyperNiche (McCune 2006) to predict the climate niche of the nine tree species and two shrub functional types. Using NPMR, species distribution responses were predicted as a function of multiplicative interactions among climate predictors, using an iterative algorithm that maximizes fit by analyzing target points in a local neighborhood in predictor space via distance-weighted smoothing functions. This process selects variables in a forward-stepwise procedure and produces multiple local models that predict the response variable as a prediction surface or curve. We used a Gaussian weighting procedure with a local mean estimator that required a minimum average neighborhood size (i.e., the number of sample units that contribute to an estimate 
of the response variable at each point. We used $5 \%$ of the sample size). Final model selection used a "leave-one-out, cross-validation" procedure to reduce over-fitting, a minimum data-to-predictor ratio (10:1), and log-likelihood ratio improvement criterion to ensure parsimony. NPMR may have advantages over other niche modeling methods (Lintz et al. 2011), including the ability to identify non-linear, multiplicative effects of climate predictors on species occurrence patterns, improving the potential to predict "multiniche" space (e.g., bimodal species responses).

Response variables used in our NPMR models included presence-absence data for each tree species derived from 8888 Forest Inventory and Analysis (FIA) plots located throughout Idaho (http://www.fia.fs.fed.us/) that included both forest and non-forest locations. The Idaho FIA dataset was large enough to include locations across substantial bioclimatic diversity (portions of seven US Environmental Protection Agency (2013) level-III ecoregions) but small enough to exclude distant populations and genotypes; thus, allowing us to model regionally adapted tree populations through their relationships with climate of the central Rocky Mountains and nearby locations. Although FIA coordinates are randomly obscured to within $1 \mathrm{~km}$ of actual sample location, predictor variable and projected species distributions have been shown to be generally statistically equivalent for models built with true versus obscured FIA locations (Gibson et al. 2014). The same FIA plot locations were also overlaid with a vegetation map developed by the LANDFIRE program (Rollins 2009; http://www.landfire. gov/) to derive random presence and absence locations for the two shrub community types. This procedure simply provided an easy way to acquire a random sample of spatially accurate locations of the shrub community types at the same sampling intensity as the tree species. All tree species and both shrub functional types used half of the presence-absence data to build the NPMR climate niche models, and the other half for validation.

Data for contemporary climate (representing the 1961-1990 climate normal period) and future climate (10-year averages centered on the years 2030, 2060, 2090) were obtained in grid format at $\sim 800 \mathrm{~m}$ resolution, from the USDA Forest Service (Crookston and Rehfeldt 2008). For future projections, we selected the Geophysical Fluid Dynamics Laboratory (GFDL) CM2.1 general circulation model, due to warmer temperatures and generally drier growing seasons projected for our study area under the B1 and A2 future emission scenarios (Fig. 2). Potential climate variables were assessed, screened, and selected to represent both seasonal and annual measures of precipitation, temperature, and their interactions (Table 1). Precipitation variables were log-transformed when this improved normality of distribution.

\section{Description of the Landis-II forest landscape simulation model}

We used LANDIS-II v6.0 (Scheller et al. 2007; http:// www.landis-ii.org/) to simulate tree species response to alternative climate and fire regime scenarios. LANDIS-II is a stochastic, spatially explicit, raster-based FLSM that simulates species-specific dispersal, establishment, competition, and mortality based on species life history traits, disturbance, and affinities to environmental conditions. LANDIS-II and its parent program, LANDIS (Mladenoff and He 1999), have proven powerful tools for exploring vegetation response to forest management (Gustafson et al. 2010; Scheller and Mladenoff 2007; Shinneman et al. 2010), fire regimes (He and Mladenoff 1999; Sturtevant et al. 2009), biological disturbances (Sturtevant et al. 2012), and climate change (Scheller and Mladenoff 2008; Xu et al. 2009; Dymond et al. 2012). In LANDIS-II, simulated landscapes are represented as a grid of interacting cells, with each cell capable of containing multiple tree or shrub species, representing one to many age cohorts. LANDIS-II does not track individual stems, rather it simulates the growth and mortality of species-age cohorts in each cell, while simulating ecological process (e.g., seed dispersal, disturbance) at the landscape scale. Whether or not a seed of a species establishes and commences growth depends on a user-provided species establishment probability (SEP) unique to each species within each ecoregion (compared against a uniform random number $(0-1)$ ), sufficient light, and available propagules. The life history characteristics defining each species' reproductive, dispersal, and competitive capacity are given in Table 2 . We used a customized version (subsequently released as v4.1) of the age-only succession extension for LANDISII that allowed us to update SEP values at each 10-year time step.

\section{Species establishment probability parameterization in LANDIS-II}

For each tree species, the probability of occurrence values predicted by the NPMR models were spatially averaged for each ecoregion and directly utilized as species establishment probabilities (SEP) values in LANDIS-II. SEPs ranging from 0.0 to 0.78 were assigned to 176 unique ecoregions that were delineated using a combination of three mapped climate variables (Table 1) and existing forest cover (see Additional file 1: Appendix 1 for detailed methods). Non-forested ecoregions were assigned SEP values of 0.0 for all tree species under contemporary climate based on the assumption that most area capable of supporting forest cover is currently occupied by trees or mountain shrubs (e.g., in recently disturbed areas) and these generally arid ecoregions have unsuitable climates for trees. SEP values for the two 


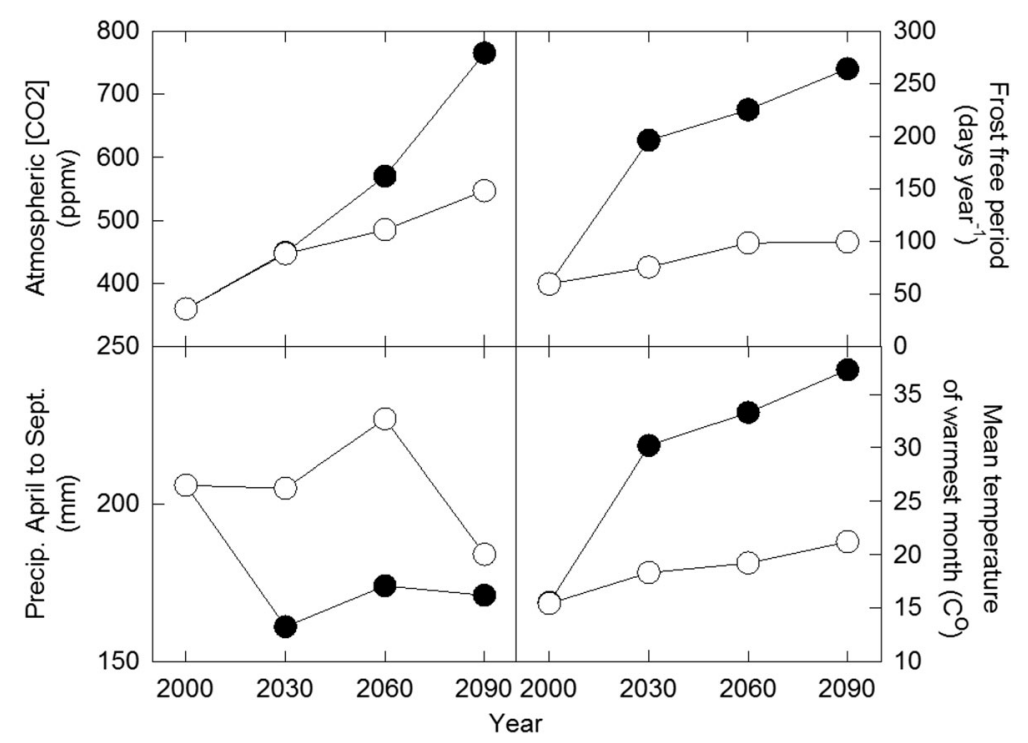

Fig. 2 Predicted climate conditions under the A2 (solid circles) and B1 (open circles) greenhouse gas emission scenarios (IPCC 2000), averaged for the entire study area. Climate data were derived from a downscaled version of the Geophysical Fluid Dynamics Laboratory (GFDL) CM2.1 general circulation model (Crookston and Rehfeldt 2008)

shrub community types were also derived from the NPMR projections but further modified to better reflect relationships with forest species (Additional file 2: Appendix 2). To incorporate the effects of climate change, SEP values were updated at 10 -year time steps in LANDIS-II by directly using the probability of occurrence projections derived from the NPMR models (described above) for the years 2030, 2060, and 2090 and by linearly interpolating values for the intervening time steps (e.g., 2040). To account for the possibility that climate change could promote tree migration into some non-forested ecoregions under changing climate, we allowed $0.0 \mathrm{SEP}$ values in semi-arid shrub-grass

Table 1 Climate predictor variables used to develop species climate niche models, using non-parametric multiplicative regression

\begin{tabular}{|c|c|}
\hline Acronym & Definition \\
\hline $\mathrm{MAP}^{\mathrm{a}}$ & Mean annual precipitation (mm)—log transformed \\
\hline GSP & $\begin{array}{l}\text { Mean growing season precipitation (mm; April-September) - } \\
\text { log transformed }\end{array}$ \\
\hline MTCM & Mean temperature $\left(\mathrm{C}^{\circ}\right)$ in the coldest month \\
\hline MTWM & Mean temperature $\left(\mathrm{C}^{\circ}\right)$ in the warmest month \\
\hline MMINDDO ${ }^{\mathrm{a}}$ & Mean degree-days $<0{ }^{\circ} \mathrm{C}$ \\
\hline DD5 & Mean degree-days $>5^{\circ} \mathrm{C}$ \\
\hline PRATIO & Precipitation ratio (GSP/MAP) \\
\hline $\mathrm{SDI} \mathrm{S}^{\mathrm{a}}$ & Summer dryness index - $\left(\sqrt{D D} 5_{\text {Apr-Sept }}\right) / G S P$ \\
\hline ADI & Annual dryness index-( لJD5)/MAP \\
\hline
\end{tabular}

assed also to delineate ecoregions in LANDIS-II model (see Additional file 1: Appendix 1).

See (Rehfeldt 2006) for methods used to develop these climate data. Climate variables are further described and data are available

at http://charcoal.cnre.vt.edu/climate/ dominated ecoregions to increase at the same rate as similar forested ecoregions (i.e., within the same climate strata combination; see Additional file 1: Appendix 1). Where land-use change or substantial soil development would be required for tree establishment (e.g., rock, snowfield, agriculture), the SEP was held constant (at $0.0)$ over time.

\section{Fire regime parameterization in LANDIS-II}

Fire was used in the model to explore the possibility that disturbance could mediate species redistribution under climate change, with variable influence among different fire regimes. In the LANDIS-II Base Fire Extension (v3.0.2), stochastically simulated fire regimes are constrained by user-determined targets for fire regime attributes (described below) that can be uniquely parametrized for different fire scenarios and different fire regions, and are further modulated by vegetation growth between fire events and species-specific tolerances to fire. Fire regions are designed to reflect patterns of geographic variation in characteristic fire regime attributes, including mean fire return interval, mean fire size, maximum fire size, ignition rate, and the time required for fuel accumulation to increase subsequent fire severity effects (Scheller et al. 2007). Fire severity also varies based on species-specific fire tolerance level (Table 2) and cohort age, with younger cohorts more susceptible to fire mortality than older cohorts (see Scheller et al. 2007).

In our model, four variables were selected to delineate fire regions (see Additional file 3: Appendix 3 for details): length of the frost-free season (as a proxy for fireseason length), growing season precipitation (a proxy for 
Table 2 Species life history attributes used in the LANDIS-II forest landscape simulation model

\begin{tabular}{|c|c|c|c|c|c|c|c|}
\hline \multirow[t]{2}{*}{ Species } & Longevity & Sexual maturity & Shade tolerance & Fire tolerance & Post-fire regeneration & $\begin{array}{l}\text { Modal seed } \\
\text { dispersal } \\
\text { distance }\end{array}$ & $\begin{array}{l}\text { Max seed } \\
\text { dispersal } \\
\text { distance }\end{array}$ \\
\hline & (years) & (years) & (5 = highest) & (5 = highest) & (mode) & $(\mathrm{m})$ & (m) \\
\hline Grand fir & 250 & 20 & 4 & 2 & In-seed & 50 & 100 \\
\hline Subalpine fir & 300 & 20 & 5 & 1 & In-seed & 50 & 100 \\
\hline Engelmann spruce & 500 & 15 & 4 & 1 & In-seed & 31 & 183 \\
\hline Whitebark pine & 500 & 20 & 2 & 2 & In-seed & 100 & 4000 \\
\hline Limber pine & 700 & 30 & 2 & 2 & In-seed & 100 & 4000 \\
\hline Lodgepole pine & 250 & 10 & 1 & 2 & Serotiny & 20 & 60 \\
\hline Ponderosa pine & 700 & 7 & 2 & 5 & In-seed & 37 & 220 \\
\hline Aspen & 200 & 10 & 3 & 1 & Resprout & 10 & 500 \\
\hline Douglas-fir & 500 & 12 & 4 & 3 & In-seed & 100 & 800 \\
\hline Mountain shrub & 200 & 3 & 3 & 1 & Resprout & 100 & 1000 \\
\hline Semi-arid shrub-grass & 250 & 3 & 2 & 1 & Resprout & 100 & 1000 \\
\hline
\end{tabular}

fuel and fuel-moisture availability), mean temperature of warmest month (a proxy for fire-season temperatures), and current forest cover (to capture fine-scale topographic influences on fire regimes not resolved in the other climate variables). The four resulting fire regions reflect a gradient from generally cold, mesic climates with shorter fire seasons to hot, dry climates with longer fire seasons, and determined fire behavior in both forested and non-forested areas (Table 3). Each of these four fire regions were distinctly parametrized within three fire regime scenarios to reflect relatively long, medium, and short fire rotations and to nominally represent suppressed, historical, and future

Table 3 Key fire scenario parameters used in the LANDIS-II forest landscape simulation model

\begin{tabular}{lllll}
\hline Fire Scenario & $\begin{array}{l}\text { Fire } \\
\text { region }^{\text {a }}\end{array}$ & $\begin{array}{l}\text { Mean rotation } \\
\operatorname{target}^{\mathrm{b}} \text { (years) }\end{array}$ & $\begin{array}{l}\text { Maximum } \\
\text { fire size } \\
\operatorname{target}^{\mathrm{b}} \text { (ha) }\end{array}$ & $\begin{array}{l}\text { Interval required } \\
\text { for highest } \\
\text { severity (years) }\end{array}$ \\
\hline $\begin{array}{l}\text { Long rotation } \\
\text { (suppressed) }\end{array}$ & 1 & 5000 & 5500 & 120 \\
& 2 & 2500 & 5500 & 250 \\
& 3 & 1200 & 6100 & 300 \\
Medium & 1 & 500 & 12,500 & 350 \\
rotation & 2 & 150 & 77,000 & 120 \\
(historical) & 3 & 120 & 61,000 & 250 \\
& 4 & 90 & 52,000 & 300 \\
Short & 1 & 100 & 92,000 & 350 \\
rotation & 2 & 80 & 77,000 & 120 \\
(future) & 3 & 60 & 61,000 & 250 \\
& 4 & 50 & 52,000 & 300 \\
\hline
\end{tabular}

${ }^{a}$ Region 1: upper montane-subalpine forests; Region 2: upper montane and northerly aspect mesic conifer forest; Region 3: lower montane and montane southerly aspect dry conifer forests; Region 4: low-elevation, non-forested, semiarid-shrublands

bANDIS-II stochastically generates fire events to approximate these targets fire regimes, respectively (Table 3). The long rotation fire regime scenario was parameterized using fire data from the 50-year period between 1934 and 1983 (Gibson and Morgan 2009) when the combined effects of climate and fire-exclusion likely contributed to a relatively small area burned in forested ecosystems. The medium rotation fire regime reflects estimates of fire rotation and severity from the pre-EuroAmerican settlement era (e.g., Morgan and Parsons 2001), but was also parameterized by simulating fire for 1000 years on a completely randomized redistribution of the initial forest community map, and iteratively adjusting fire parameters until forest community proportions and distributions reached a quasi-equilibrium and resembled expected historical forest patterns. The short rotation fire regime scenario represents potential influence of a warming and drying climate and was calculated using fire rotation and size trends derived from MTBS data (Eidenshink et al. 2007) for the most recent 30-year period (1984-2013), which has experienced substantial increase in average area burned compared to the previous 50-year period. The resulting future fire parameters (Table 3) are reasonable given contemporary trends, though potentially conservative based on recently modeled fire projections for the western USA (e.g., Westerling et al. 2011; Hawbaker and Zhu 2012, Barbero et al. 2015).

\section{LANDIS-II simulations}

LANDIS-II requires an initial, spatially explicit vegetation map that has tree species and age cohorts assigned to different plant community types. We constructed this initial community map by spatially interpolating FIA stand data with LANDFIRE community types (Additional file 4: Appendix 4). However, in order to attribute any changes in species distributions to our manipulation of climate and fire in LANDIS-II, we needed to be confident that 
simulated vegetation dynamics were at or near equilibrium (ideally reflecting contemporary forest landscape conditions) before implementing changes in climate or fire regime. Thus, we ran the model under historical fire and contemporary climate conditions until plant community composition reached a state of quasi-equilibrium (after $\sim 600$ years), and then verified that the resulting composition and distribution approximated contemporary landscape conditions (Additional file 4: Appendix 4). Each alternative future scenario was simulated after this preceding 600-year initialization period, to ensure that effects documented for the alternative future scenarios were not due to initial self-regulating model behavior. We then ran nine alternative models, by fully crossing the three climate scenarios (contemporary climate and the B1 and A2 s climate scenarios) with the three fire regime scenarios (suppressed, historical, future).

\section{Results}

NPMR projections of climate change effects on the geographic distribution of niche space

The selected NPMR models reasonably reflected the unique climate niche for each species and the arid shrub community type, and adequately predicted species distributions in our study area based on AUC results (range 0.81-0.93 for all but mountain shrub) for the validation datasets of presence and absence locations (Table 4). NPMR models also reflected the unique responses of each species to climate change. Given limited amount of high-elevation land available for tree establishment, warming conditions under both climate scenarios contracted favorable locations for establishment for Douglas-fir, lodgepole pine, and subalpine fir to higher elevations, though much more substantially for the A2 than B1 climate scenario (Fig. 3). In contrast, area favorable for ponderosa pine expanded under both future climate scenarios. Under the hotter and drier climates predicted in the A2 scenario, climate niche space favorable for ponderosa pine shifted from lower to higher elevations while under the B1 scenario, the upward shift in elevation was somewhat less pronounced, as warmer and temporarily wetter climates permitted greater expansion into elevation zones already occupied (Fig. 3). For Douglas-fir, lodgepole pine, and subalpine fir, locations favorable for establishment was reduced to approximately one third of current levels by 2090 under the $\mathrm{B} 1$ climate change scenario and to nearly zero by 2090 under the A2 scenario. For ponderosa pine, locations favorable for establishment (establishment probability >0.20) expanded by 94 and $41 \%$ by 2090 under the B1 and A2 climate scenarios, respectively.

\section{Simulated effects of fire regime and climate change on species distribution and abundance}

Based on FLSM simulations, the spatial distribution, total area occupied (i.e., number of 1-ha pixels with a cohort present), and rate of change in area occupied for each tree species varied by fire regime and climate change scenarios (Figs. 4 and 5). Under the current climate scenario, the historical fire regime resulted in relatively steady occupancy rate for all species over the 90-year model period (Fig. 4). Under current climate

Table 4 Climate niche models developed for each tree species and two shrub community types

\begin{tabular}{|c|c|c|c|c|c|}
\hline Species & Model predictors ${ }^{a}$ (tolerance) & $\log B$ & $A \cup C$ & Model presence $(n)$ & Validation presence $(n)$ \\
\hline Grand fir & MTCM (1.35) LogMAP (0.04) logGSP (0.08) & 510.2 & 0.93 & 971 & 930 \\
\hline Subalpine fir & DD5 (134.25) LogMAP (0.09) PRATIO (0.07) & 424.0 & 0.89 & 1224 & 1220 \\
\hline Engelmann spruce & SDI (0.03) DD5 (268.50) LogMAP (0.04) & 238.6 & 0.86 & 779 & 772 \\
\hline Whitebark pine & MTWM (0.86) MTCM (0.68) & 227.1 & 0.93 & 348 & 351 \\
\hline Limber pine & MTWM (1.72) MTCM (0.68) PRATIO (0.05) & 63.6 & 0.93 & 78 & 69 \\
\hline Lodgepole pine & SDI (0.03) MTCM (2.03) LogMAP (0.04) & 247.1 & 0.81 & 1142 & 1149 \\
\hline \multirow[t]{2}{*}{ Ponderosa pine } & MTWM (1.72) MMINDD0 (375.70) & 247.7 & 0.89 & 584 & 552 \\
\hline & $\log M A P(0.04)$ & & & & \\
\hline Aspen & MTWM (1.72) MTCM (1.35) LogMAP (0.04) & 122.5 & 0.87 & 309 & 293 \\
\hline Douglas-fir & ADI (0.01) MTWM (0.86) MTCM (1.35) & 327.1 & 0.82 & 2268 & 2218 \\
\hline \multirow[t]{2}{*}{ Mountain shrub } & MTWM (1.72) MMINDD0 (375.70) & 11.9 & 0.66 & 101 & 93 \\
\hline & PRATIO (0.05) logGSP (0.12) & & & & \\
\hline Semi-arid shrub-grass & ADI (0.01) SDI (0.03) MTCM (0.68) & 271.5 & 0.81 & 1420 & 1185 \\
\hline
\end{tabular}

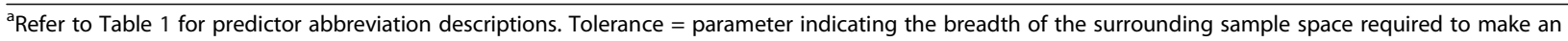
estimate for a given point in the model (specifically, the standard deviation of the Gaussian weighting function for each predictor, given in original units for each predictor). $\log B=\log 10$ (likelihood ratio), indicating improvement of a new model over the naïve model (i.e., where the probability of encountering the species is the average frequency of occurrence of the species). $\log B$ values vary with number of presence points; thus, is not a good comparison metric among species models. AUC $=$ area under receiver operating characteristic (calculated for validation on the new sites). Model presence = number of presence points for the model (out of 4445 ). Validation presence $=$ number of presence points in the validation dataset (out of 4443) 


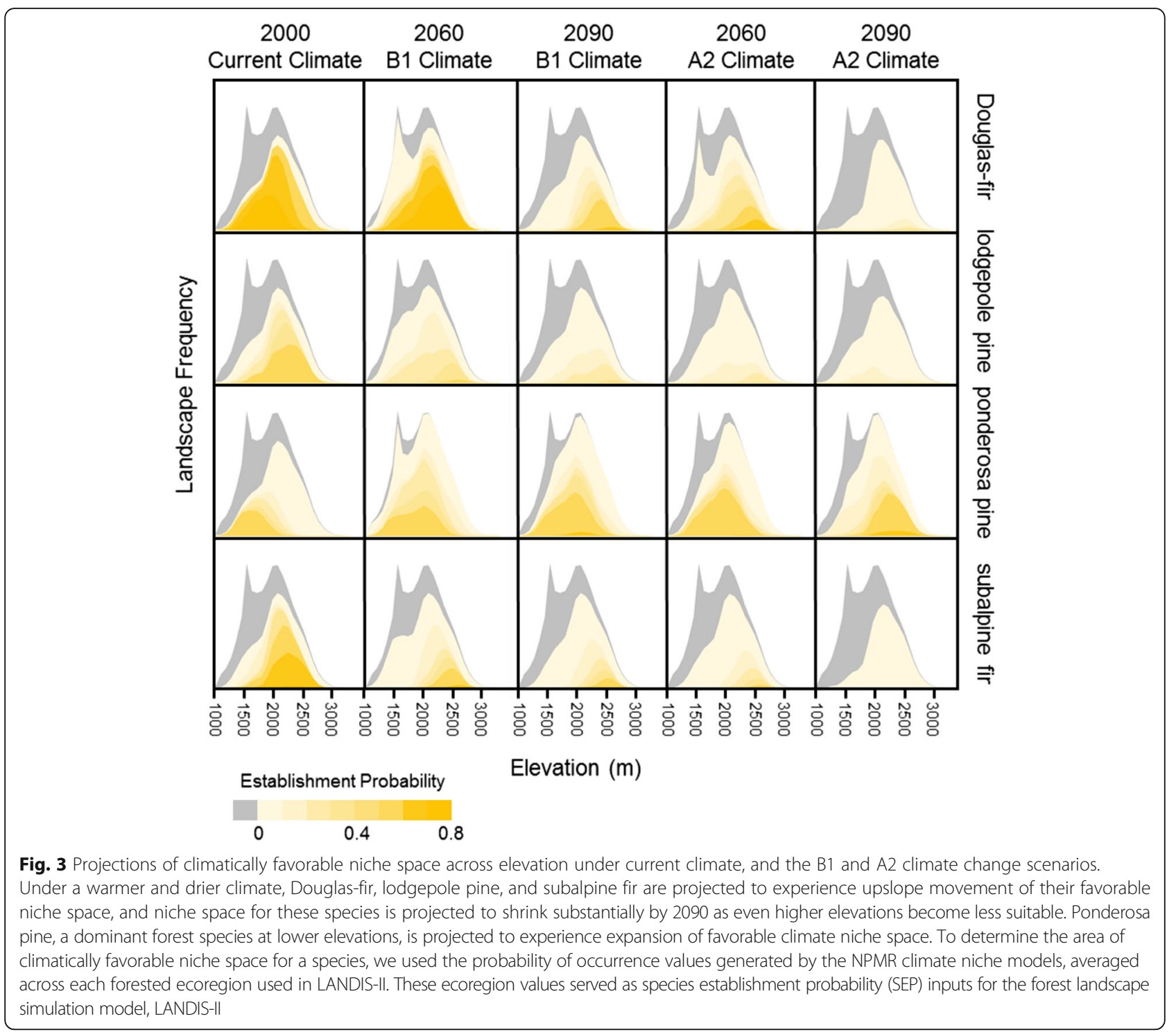

and suppressed fire regime, the area occupied by subalpine fir and Douglas-fir increased over time, while ponderosa pine and lodgepole pine decreased. The opposite trend occurred under current climate and the future fire regime, as subalpine fir and Douglas-fir generally decreased in area over time, while ponderosa pine and lodgepole pine increased (though only slightly and temporarily for the latter species). The response of lodgepole pine to fire regime was the most erratic, benefiting at different times from both suppressed and future fire regimes (Fig. 4), and suggesting a dynamic relationship with fire due to its relatively low fire tolerance (resulting in high mortality rates) contrasted with its ability to quickly recover after fire through serotiny.

Under climate change, a continuation of the historical fire regime led to a slight to modest reduction in abundance of Douglas-fir by 2090 depending on climate scenario (8 and 29\% reduction compared to 2000 levels for the B1 and A2 scenarios, respectively); the suppressed fire regime resulted in a similar increase in abundance under both climate change scenarios (stabilizing at 128 and $121 \%$ over year 2000 levels by 2060 for the $\mathrm{B} 1$ and $\mathrm{A} 2$ scenarios, respectively), and the future (short rotation) fire regime resulted in a decrease in abundance, but much more sharply for the A2 (65\% reduction) than the B1 (47\% reduction) scenario (Fig. 4). The influence of fire regime and climate change on the abundance of subalpine fir was similar in pattern and magnitude to that of Douglas-fir, with the exception that fire suppression did not as effectively shield subalpine fir from the effects of climate change (Fig. 4). That is, while fire suppression did result in a net increase in the abundance of subalpine fir under all climate scenarios, the benefits of less fire were tempered by climate change. 


\section{Current Climate vs B1}

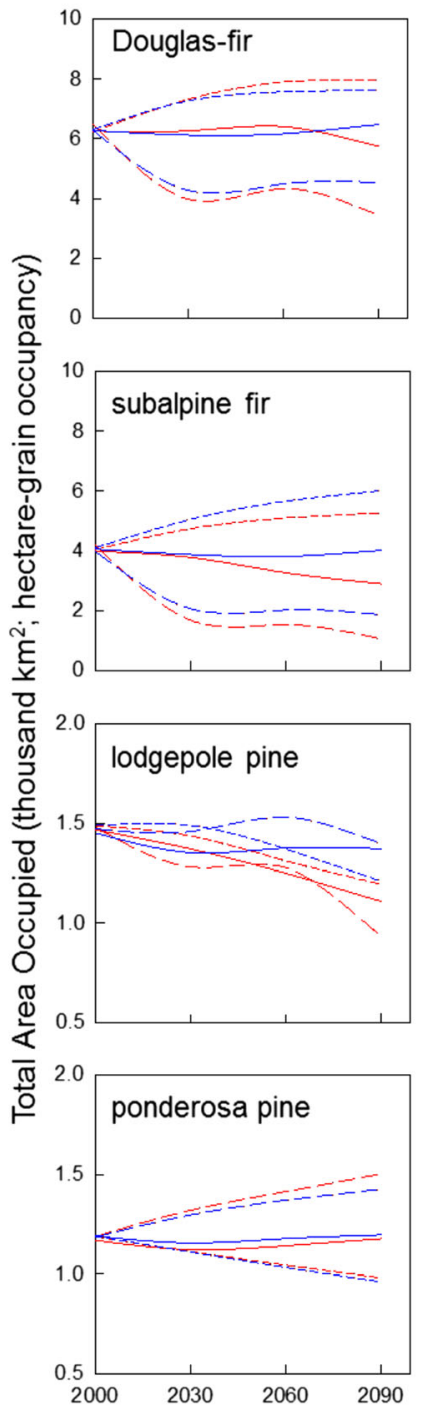

Current Climate vs A2
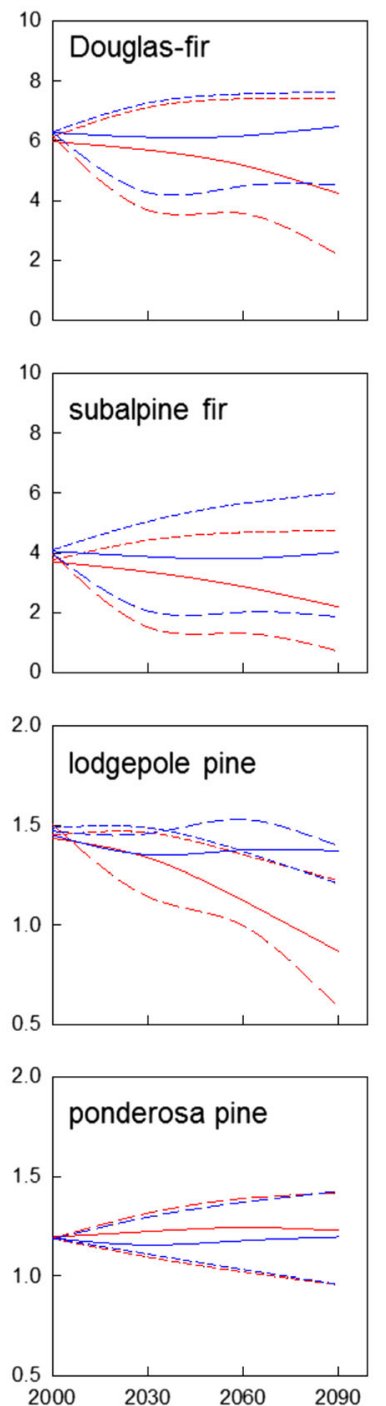

\section{— static current climate, historical fire ----- static current climate, suppressed fire} - climate change, historical fire
---- climate change, suppressed fire
- - - climate change, future fire

Fig. 4 Species abundance over 90 years of continued contemporary climate compared to B1 and A2 climate change scenarios under suppressed, historical, and future fire regimes. The relative equilibrium of the area occupied by each species maintained under a continuation of the current climate and historical fire regime served as a baseline to compare simulated effects of alternative fire-climate scenarios. Under both the B1 and A2 climate scenarios, increasing fire frequency accelerated simulated climate-driven declines in Douglas-fir, lodgepole pine, and subalpine fir. Increasing fire frequency favored ponderosa pine similarly under all climate scenarios, though slightly more so under the B1 climate change scenario. Species occupancy is defined as the presence of at least one age cohort in a 1-ha grid cell

For ponderosa pine, a suppressed fire regime led to nearly identical declines in abundance under both climate change scenarios compared to year 2000 ( 18\% decline by year 2090), while the future fire regime resulted in a somewhat greater increase in abundance by 2090 for the B1 (27\%) compared to the A2 climate scenarios (19\%). Notably, the influence of climate change on the abundance of ponderosa pine was negligible to only slightly positive relative to current climate, depending on fire regime, despite a large increase in the area newly suitable for establishment. The simulated effects of climate change and fire regime are more complicated for lodgepole pine, which was faced with a substantial reduction in area climatically suitable for establishment 


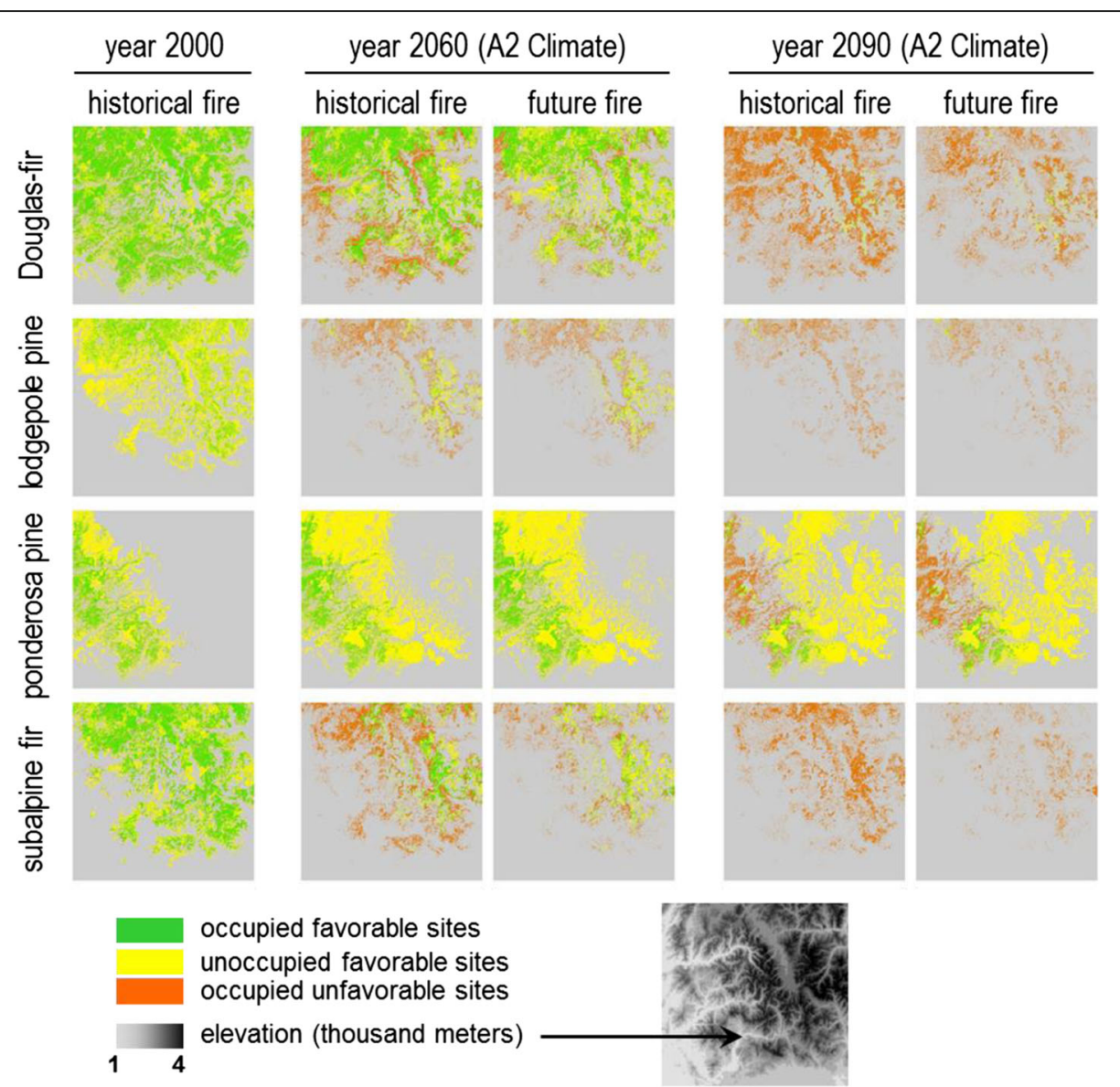

Fig. 5 Modeled contemporary and future species occupancy relative to climatically favorable locations. Year 2000 distributions reflect the landscape after 600 simulated years of contemporary climate and the historical fire regime. Year 2060 and 2090 distributions illustrate a geographic disequilibrium under the A2 climate scenario for both a continuation of the historical fire regime and a future (higher frequency) fire regime. Under the A2 scenario, persistence in climatically unfavorable locations is substantial for Douglas-fir, subalpine fir, and lodgepole pine, although increased fire frequency reduces this persistence. In contrast, ponderosa pine loses little of its favorable habitat and benefits from fire in areas that remain favorable. Species occupancy is defined as the presence of at least one age cohort in a 1-ha grid cell, and climatic favorability is defined as a location where climatically-defined species establishment probabilities (SEP) exceed 0.2

under both climate change scenarios (Fig. 3). Lodgepole pine declined over time under both climate change scenarios, more so under the future fire regime than under the suppressed fire regimes. For example, under the A2 climate change scenario, lodgepole pine declined between year 2000 and 2090 by $60 \%$ under the future fire regime, but by only $18 \%$ under the suppressed fire regime.

\section{Species persistence under unfavorable conditions and expansion into newly favorable conditions}

Persistence for three of the tree species (lodgepole pine, Douglas-fir, subalpine fir) throughout the 90-year simulation under either climate change scenario was afforded almost entirely by sites that grew increasingly unfavorable for new establishment (Fig. 5). As a result, the median favorability of sites occupied by these three species dropped substantially over the 90-year simulation period, particularly for simulations under the A2 climate scenario (Fig. 6). Under A2 climate, the mean favorability (based on species establishment probabilities-SEPs) for Douglas-fir was $\sim 0.7$ for the simulated contemporary period, declined to $\sim 0.5$ by 2030 under all fire regime scenarios, and was nearly zero by 2090 . Lodgepole pine started with a mean SEP value of slightly less than 0.5 , but quickly dropped to 0.1 or less for the remainder of the model period. Subalpine fir declined less rapidly, but reached a similar low mean favorability values by 2090 . Ponderosa pine was unique in that favorability of occupied sites initially increased, but then declined substantially by year 2090 to $\sim 0.1$ across all fire scenarios. In only a few cases did fire appreciably affect trends in favorability values, including Douglas-fir, for which the favorability of occupied sites under the future fire regime was higher than other fire scenarios at 2060, and subalpine fir, for which the favorability ranges (but not 


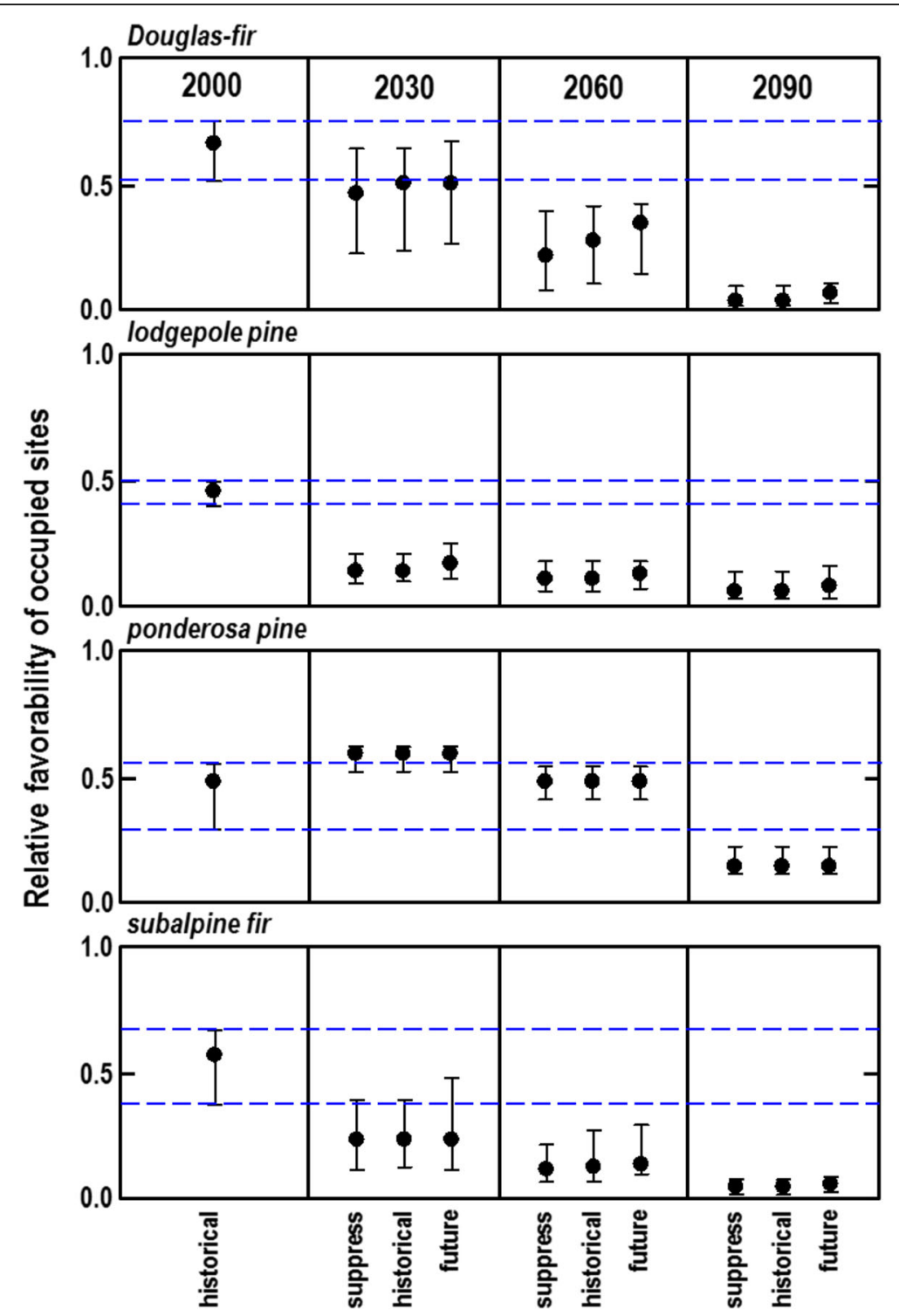

Fig. 6 Relative climatic favorability of occupied sites for tree species over 90 years of A2 climate change under suppressed, historical, and future fire regimes. Year 2000 conditions reflect 600 simulated years of contemporary climate and the historical fire regime. As trees persist in locations increasingly unfavorable for establishment, average favorability of occupied sites declines. Only for Douglas-fir and subalpine fir does a shorter fire rotation temporally reveal this tension, especially at year 2060, by killing trees in newly unsuitable locations and increasing overall favorability values. Site favorability is defined as the species establishment probability (SEP) derived from the climate niche models. Dots represent median value, error bars are the 20th and 80th percentiles, blue lines reference 20th and 80th percentiles at year 2000

means) of occupied sites noticeably varied among fire regimes for both 2030 and 2060. However, these trends were due to fire-induced mortality that reduced the occupancy rate of less favorable sites and not due to expansion of these species into newly favorable sites. Indeed, even ponderosa pine, the only species which gained favorable area (operationally defined as area where climate alone predicts an establishment probability $>0.20$ ) over the entire model period, was only able to occupy $2 \%$ or less of that newly favorable habitat over time (Fig. 5).

\section{Discussion}

While bioclimatic niche or species distribution modeling is useful for the practical task of identifying potential species range shifts relative to current species climate niches, such models do not typically estimate a direct demographic response to climate change or reflect the influence of dispersal limitations, interspecific competition, or disturbance (Franklin 2013). Yet, such biological and disturbance processes are expected to interact and serve as key drivers of rapid ecological change in plant communities under future climate change (Allen et al. 2010). 
Only a few studies using climate niche modeling approaches have attempted to integrate the role of disturbance, dispersal, or competition (Tucker et al. 2012; Crimmins et al. 2014, Maguire et al. 2015), in part due to complexities involved in integrating complex processes into non-process-based models. These additional dynamics have been more commonly simulated under climate change using FLSMs (e.g., Yang et al. 2015) and dynamic global vegetation models (e.g., Conlisk et al. 2012). However, the complexity of such models can obscure fundamental species-climate relationships that determine future climate niche distributions and may be relevant to formulating future conservation actions (e.g., assisted migration). An integrated approach allows utilization of the benefits of both types of models (e.g., Swab et al. 2012, Halofsky et al. 2014) and an opportunity to directly enhance climate niche projections via additional species response and disturbance dynamics.

\section{Geographic shifts in niche-space in response to climate change}

Based on our climate niche modeling results, many montane and subalpine conifer species in the central Rocky Mountains may experience range contraction under climate change, as climatically favorable sites available for Douglas-fir, lodgepole pine, and subalpine fir are projected to contract dramatically in our study area landscape, almost to the point of regional extirpation under the A2 climate scenario (Fig. 3). Subalpine fir and Douglas-fir may be at risk because both require relatively moist soil conditions during the growing season, especially at middle and lower elevations, and hotter and drier temperatures can result in soil moisture stress (Ettl and Peterson 1995, Case and Peterson 2005, Schrag et al. 2008). Although moderately drought tolerant, lodgepole pine is associated with climates of relatively cold nighttime and spring temperatures, and its frost-tolerant seedlings may provide competitive advantage over other conifers (e.g., Douglas-fir) in these areas (Lotan and Critchfield 1990, Coops et al. 2005).

In contrast, the climate niche for ponderosa pine, a mid- to lower montane tree species, is projected to expand under both the B1 and A2 climate scenarios based on our climate niche models. Ponderosa pine prospers under moderately warm climates with adequate winter and early growing season precipitation (Oliver 1990), especially for Pinus ponderosa var. ponderosa (Shinneman et al. 2016), which is the variety present in our study area landscape. Thus, ponderosa pine may have the greatest potential for expansion of its current climate niche, including an upward elevation shift, especially in response to the generally wetter winters predicted by both emission scenarios (data not shown).
Our NPMR projections for these four conifer species under climate change are similar to other modeled distributions of Rocky Mountain tree species under future climates. For instance, Bell et al. (2014b) developed species distribution models that predicted high-suitability habitat for Engelmann spruce, subalpine fir, and lodgepole pine would nearly disappear by 2070-2099 under the A2 climate scenario, while habitat for ponderosa pine was projected to increase in the central Rocky Mountains. Similarly, Rehfeldt et al. (2014) used a random forest classification model to project ponderosa pine and Douglas-fir climate niche space through 2060 under the RCP60 (medium-high) emissions scenario, and predicted a net gain for ponderosa pine in the central Rocky Mountains (particularly in the central Idaho region), while projecting a loss of Douglas-fir habitat at lower elevations.

\section{Potential for fire to mediate species redistribution}

Importantly, our FLSM simulations suggest the distribution of these species under future climates do not keep pace with changes in the distribution of sites climatically favorable for their establishment, due primarily to the persistence of remnant populations in increasingly unfavorable habitat, the inability of species to migrate quickly to newly favorable habitat (Fig. 5), and spatially specific effects of fire, which appear just as important in controlling species abundance as climate change effects on establishment (Fig. 4). Our simulations reinforce concerns that plant species migration may not keep pace with changing climate, in large part due to limited dispersal distances (Zhu et al. 2012, Corlett and Westcott 2013), and they reveal just how important persistence in unfavorable sites may be in temporarily maintaining species occupancy under future climate change. For instance, even under the more dramatic drying and warming climate of the A2 climate scenario and a continuation of the historical fire regime, Douglas-fir and subalpine fir occupied almost no newly favorable sites (which were few or temporary) but were projected to occupy roughly 87 and $78 \%$ of their former habitat at model year 2060 as trees in unburned habitat persisted until reaching maximum age in increasingly unfavorable climates. Temporary persistence is, however, not assured for all species. Lodgepole pine, a shorter-lived species, declined immediately and dramatically under the A2 climate change scenario in our model under both historical and future fire regimes (Figs. 4 and 5), due to senescence of older stands, fire mortality, and inhospitable conditions for regeneration. Moreover, climate-induced disturbance events (e.g., drought dieback) that were not modeled would also reduce residency time for tree populations located in increasingly unfavorable sites. 
It is not surprising that increasing the frequency of stand-replacing wildfire might reduce the persistence of trees occupying sites no longer favorable for their establishment. For instance, stand-replacing wildfires in Oregon forests along an elevation gradient resulted in unsuccessful regeneration of ponderosa pine at lower elevation ranges, because soil moisture was insufficient for spring growth of the seedling taproot (Dodson and Root 2013). On the other hand, by removing existing vegetation, disturbance events such as wildfire could also provide opportunities for tree species to exploit new climatically favorable space, as has been demonstrated via aspen seedling establishment after logging activity in upslope locations (Landhäusser et al. 2010). However, that did not happen for the two highly fire-adapted conifer species tracked in our simulations, primarily due to dispersal limitations relative to the limited availability of climatically favorable, post-fire environments over the short time period modeled. Lodgepole pine was hindered by both short-distance seed dispersal (100 m maximum) and increasingly unfavorable climate. The maximum dispersal distance $(220 \mathrm{~m})$ for ponderosa pine, a species that gained higher elevation habitat under climate change (Fig. 3), was also apparently inadequate over the 90 -year model period to reach recently burned areas in newly favorable upslope sites.

The lack of conifer establishment under climate change at higher elevations may have also been hindered by competition with mountain shrubs or other tree species that shade out arriving seeds of conifers. Several mountain shrub species and aspen are capable of quick recovery after fire, due to long-distance seed dispersal or resprouting capacity (Baker 2009). Indeed, field research has shown that even on sites where ponderosa pine was historically dominant, severe fire may lead to prolonged dominance of shrubland communities (Savage and Mast 2005), and reestablishment of ponderosa pine may require several years to more than a century (Kaufmann et al. 2003, Roccaforte et al. 2012). It is unlikely that our modeled species parameters (Table 2) unrealistically prevented successful dispersal and colonization of newly available sites under climate change, because identical competition and dispersal parameters did not hinder conifer species prominence during the 600-year initialization period (Additional files 2 and 4: Appendices 2 and 4$)$.

\section{Model assumptions and limits to interpretation}

Despite pairing climate niche and FLSM modeling approaches in order to overcome potential weaknesses of either model alone, there are several potential limitations to consider. Foremost, although our goal was to focus on examining potential regional tree population responses (vulnerabilities and opportunities for migration) to alternative fire regime and future climate scenarios, our model output was not intended to be prognostic. Rather, our model served as a preliminary investigation into the potential role of these dynamics in shaping future forest redistribution. To accomplish this goal, we limited and simplified the many complex ecological processes and their interactions that will ultimately determine future forest composition and distribution. For instance, our model relied on simple age-based competition for light resources, rather than more complex growth-based competition for multiple resources (e.g., de Bruijn et al. 2014), and the direct effects of climate on mortality (e.g., drought) were not considered. Moreover, we did not create definitive climate niche models based on range-wide data for each species, and our modeled predictions should be considered within this limited regional context. Similarly, we could not anticipate species' affinities to novel climate space (Neilson et al. 2005; Rehfeldt et al. 2012), nor did we consider that current plant distributions may be a legacy of former, undescribed climate relationships (Valclavik and Meentemeyer 2012; Garcia-Valdes et al. 2013). Indeed, although dominance, productivity, and recruitment of Rocky Mountain conifers remain highest where occurrence is highest, marginal discrepancies between the climatic spaces occupied by seedlings and their conspecific adults might suggest that climate-induced range contraction is already underway for montane conifers in the Rocky Mountains (Bell et al. 2014a).

Successful tree establishment after wildfire depends on factors such as distance to seed source, post-fire growing conditions influenced by fire severity (e.g., soil impacts, live tree retention), other disturbance agents (e.g. drought and insects), and interspecific competition (Turner et al. 1997, Donato et al. 2009, Dodson and Root 2013, Savage et al. 2013, Hansen et al. 2016; Harvey et al. 2016). However, in our simulations, post-fire establishment of the four conifer species in climatically favorable locations was limited primarily by distance to reproductively mature seed source and competition with other vegetation. Moreover, dispersal dynamics and interspecific competition under climate change are likely to include complex species responses that will need to be better represented in subsequent modeling efforts (Travis et al. 2013). For instance, our study does not consider individual years that may be exceptionally favorable for establishment along the critically important leading edges of geographically shifting climate. Also, dispersal and successful establishment of species, such as ponderosa pine, may occasionally exceed maximum dispersal distances modeled here (e.g., Haire and McGarigal 2010), and incorporating rare, long-distance dispersal events into future models may be important. Although our model allowed for the establishment of 
trees in non-forested ecoregions under climate change, perhaps unrealistically allowing forests to replace wellestablished semi-arid shrub communities in some cases, this rarely happened in our model, as most non-forested locations either remained inhospitable to tree establishment, retained relatively high shrub establishment or, if tree establishment probabilities improved, they were generally in non-forest ecoregions too remote for tree dispersal. For example, in the most extreme case, only about $7 \%$ of the original non-forest ecoregion area was converted to forest by year 2090 .

Other limitations also likely affected our future projections of tree species distribution in this research, including both GCM selection and downscaling for regional applications. Future precipitation patterns in particular remain uncertain among alternative climate models (Mote and Salathe 2010). In addition, averaging annual climate parameters over 10-year time steps excludes realistic temporal climate variability, including intermittent climate extremes that significantly affect plant demography (e.g., Allen et al. 2010). Also, although our simulated fire regimes bracketed a wide range of fire rotations, future fire regimes may be more extreme than modeled here (e.g., Barbero et al. 2015). Similarly, our simulations did not consider other disturbance agents (e.g., insects) or stress-related tree mortality (e.g., from drought) that are likely to be enhanced by climate change (Allen et al. 2010, Gustafson and Shinneman 2015), and thus likely to effect the persistence of trees in unfavorable sites.

Finally, we acknowledge that model inputs, assumptions, and scenarios can greatly affect simulated projections of forest species distributions under future climates. For instance, Yang et al. (2015) used LANDIS-II to project change in forest cover in a mountain range in northern Nevada and, although their findings regarding climate-fire influence on montane vegetation were generally similar to this study, they did not predict subalpine fir would decline as rapidly. Such differences could be due to regional climate and vegetation differences but were also likely due to use of different global climate models, slightly different species parameters, unique fire regime scenarios, and alternative methods for calculating species establishment probabilities. These differences underscore the need for future forest modeling research that emphasizes multimodel comparisons and multi-variable sensitivity tests, and suggests caution is warranted in relying on model projections beyond suggesting possible futures, and as a means to explore key relationships between species, changing climate, and disturbance regimes.

\section{Conclusions}

Migration lag is a serious potential limitation for tree species under both ongoing and expected future climate change (Zhu et al. 2012, Corlett and Westcott 2013; Travis et al. 2013). Yet, the redistribution of plant communities in response to future climate change is difficult to predict, not only because of uncertain physiological response of species to coarsely defined alternative climate projections, but also due to uncertain demographic response to altered processes, especially disturbance. Our model results support a growing appreciation that near-future climate change, even under modest increases in greenhouse gas emissions, will likely result in a substantial upslope shifts of the climate space required by current populations of tree species. For low- to midelevation species, such as ponderosa pine, such change represents a potential expansion opportunity, while favorable habitat for higher elevation species will likely dwindle. The degree to which wildfire or other disturbance will break the inertia afforded by long tree life spans in increasingly unfavorable climate remains an important research question. Our 90-year simulations suggest that increased rates of stand-replacing fire might not substantially accelerate upslope immigration of trees into newly favorable-locations, largely due to seed dispersal limitation and possible competition from shrubs already present and suited to altered climate. Rather, our results suggest that fire is far more likely to eliminate tree species populations along the trailing edge of their distribution under increasingly unfavorable climate, although some long-lived species (Douglas-fir) might persist longer in these locations with less frequent fire. Future research combining empirical observation, process simulation, and manipulative experimentation is needed to further determine the relative influence among dispersal, establishment, and competition dynamics in post-fire environments under continuing climate change.

\section{Additional files}

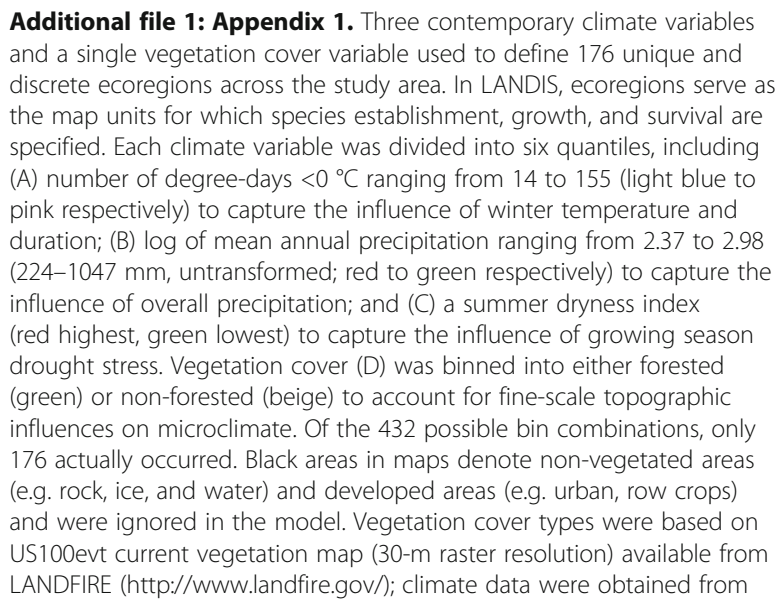


the USDA Forest Service (http://charcoal.cnre.vt.edu/climate/details.php). (DOCX $700 \mathrm{~kb})$

Additional file 2: Appendix 2. We included the two shrub community types in LANDIS-II in order to provide a non-forest component that could co-occur with forest species and potentially dominate in their absence (i.e., temporarily after wildfire, and permanently if forest species are not supported by climate conditions).(DOCX $1055 \mathrm{~kb}$ )

Additional file 3: Appendix 3. Maps demonstrating (A) fire regions and (B) an example of fires simulated by LANDIS-II during a single 10year time step. Fire regions were delineated using a length of frost-free season (a proxy for fire-season length), growing season precipitation (a proxy for fuel-moisture availability), mean temperature of warmest month (a proxy for fire-season temperatures), and current forest cover (to capture fine-scale topographic influences on fire behavior not resolved in the other climate variables). Vegetation cover types were based on US100evt current vegetation map available from LANDFIRE (http://www.landfire.gov/); climate data were obtained from the USDA Forest Service (http://charcoal.cnre.vt.edu/climate/ details.php). (DOCX $313 \mathrm{~kb}$ )

Additional file 4: Appendix 4. The vegetation community map used to initiate the LANDIS-II forest landscape simulation model was created to represent current vegetation distribution across our study area, and contains information on the presence or absence (within each $100 \mathrm{~m} \times$ $100 \mathrm{~m}$ grid cell) of nine tree species and two shrub functional types (Table 2) by 10-year cohorts. (DOCX $300 \mathrm{~kb}$ )

\section{Acknowledgements}

We would like to thank Sean Finn for the GIS and data preparation assistance that contributed to this research; Robert Scheller for the assistance with LANDS-II modifications, conceptual modeling guidance, and review of an earlier draft of this manuscript; and Kaitlin Maguire, Eric Gustafson, and two anonymous reviewers for the helpful suggestions that improved this manuscript. Any use of trade, product, or firm names is for descriptive purposes only and does not imply endorsement by the US Government. This article has been peer reviewed and approved for publication consistent with the USGS Fundamental Science Practices (http://pubs.usgs.gov/circ/1367).

\section{Authors' contributions}

DJS conceived of the study and developed the species-specific climatic niche models. JLC and DJS parametrized the forest landscape model and wrote the manuscript text. JLC conducted and analyzed the forest landscape simulations and crafted the manuscript figures. Both authors read and approved the final manuscript.

\section{Competing interests}

The authors declare that they have no competing interests.

\section{Author details}

'Department of Forest Ecosystems and Society, Oregon State University, Corvallis, OR, USA. ${ }^{2}$ U.S. Geological Survey, Forest and Rangeland Ecosystem Science Center, Boise, ID, USA.

Received: 6 December 2016 Accepted: 21 January 2017 Published online: 09 February 2017

\section{References}

Abatzoglou JT, Kolden CA (2011) Climate change in western US deserts: potential for increased wildfire and invasive annual grasses. Rangel Ecol Manag 64(5): $471-478$

Allen CD, Macalady AK, Chenchouni H, Bachelet D, McDowell N, Vennetier M, Kitzberger T, Rigling A, Breshears DD, Hogg EH, Gonzalez P, Fensham R, Zhang Z, Castro J, Demidova N, Lim JH, Allard G, Running SW, Semerci A, Cobb N (2010) A global overview of drought and heat-induced tree mortality reveals emerging climate change risks for forests. For Ecol Manag 259:660-684

Bachelet D, Lenihan J, Neilson R, Drapek R, Kittel T (2005) Simulating the response of natural ecosystems and their fire regimes to climatic variability in Alaska. Can J For Res 35:2244-2257

Baker WL (2009) Fire ecology in Rocky Mountain landscapes. Island Press Washington DC, USA
Bakkenes M, Alkemade JM, Ihle F, Leemans R, Latour JB (2002) Assessing effects of forecasted climate change on the diversity and distribution of European higher plants for 2050. Glob Chang Biol 8(4):390-407

Barbero R, Abatzoglou JT, Larkin NK, Kolden CA, Stocks B (2015) Climate change presents increased potential for very large fires in the contiguous United States. Int J Wildland Fire 24:892-899

Bell DM, Bradford JB, Lauenroth WK (2014a) Early indicators of change: divergent climate envelopes between tree life stages imply range shifts in the western United States. Glob Ecol Biogeogr 23:168-180

Bell DM, Bradford JB, Lauenroth WK (2014b) Mountain landscapes offer few opportunities for high-elevation tree species migration. Glob Change Biol 20: 1441-1451

Boisvenue C, Running SW (2006) Impacts of climate change on natural forest productivity-evidence since the middle of the 20th century. Glob Chang Biol 12:862-882

Boisvenue C, Running SW (2010) Simulations show decreasing carbon stocks and potential for carbon emissions in Rocky Mountain forests over the next century. Ecol Appl 20(5):1302-1319

Brunelle A, Rehfeldt GE, Bentz B, Munson AS (2008) Holocene records of Dendroctonus bark beetles in high elevation pine forests of Idaho and Montana, USA. Forest Ecology and Management 255 (3-4):836-846.

Case MJ, Peterson DL (2005) Fine-scale variability in growth-climate relationships of Douglas-fir, North Cascade Range, Washington. Can J For Res 35:2743-2755

Conlisk E, Lawson D, Syphard AD, Franklin J, Flint L, Flint A, Regan HM (2012) The roles of dispersal, fecundity, and predation in the population persistence of an oak (Quercus engelmannii) under global change. PLoS ONE 7(5):e36391, doi:10.1371/journalpone0036391

Conlisk E, Syphard AD, Franklin J, Flint L, Flint A, Regan HM (2013) Uncertainty in assessing the impacts of global change with coupled dynamic species distribution and population models. Glob Chang Biol 19:858-869

Coops NC, Waring RH, Law BE (2005) Assessing the past and future distribution and productivity of ponderosa pine in the Pacific Northwest using a process model, 3-PG. Ecol Model 183(1):107-124

Corlett RT, Westcott DA (2013) Will plant movements keep up with climate change? Trends Ecol Evol 28(8):482-488

Crane MF, Fisher WC (1986) Fire ecology of the forested habitat types of central Idaho. In: USDA Forest Service General Technical Report INT-218 Intermountain Research Station

Crimmins SM, Dobrowski SZ, Mynsberge AR, Safford HD (2014) Can fire atlas data improve species distribution model projections? Ecol Appl 24(5):1057-1069

Crookston NL, Rehfeldt GE (2008) Climate estimates and plant-climate relationships. USDA Forest Service, Moscow ID, Available: http://charcoal.cnre.vt.edu/climate/ details.php

Daubenmire R (1956) Climate as a determinant of vegetation distribution in eastern Washington and northern Idaho. Ecol Monogr 26:131-154

de Bruijn A, Gustafson EJ, Sturtevant BR, Foster JR, Miranda BR, Lichti NI, Jacobs DF (2014) Toward more robust projections of forest landscape dynamics under novel environmental conditions: embedding PnET within LANDIS-II. Ecol Model 287:44-57

Dodson EK, Root HT (2013) Conifer regeneration following stand-replacing wildfire varies along an elevation gradient in a ponderosa pine forest, Oregon, USA. For Ecol Manag 302:163-170

Donato DC, Fontaine JB, Campbell JL, Robinson WD, Kauffan JB, Law BE (2009) Conifer regeneration in stand-replacement portions of a landscape-scale mixed-severity wildfire. Can J For Res 39:823-838

Dymond CC, Scheller RM, Beukema S (2012) A new model for simulating climate change and carbon dynamics in forested landscapes. J Ecosyst Manage 13(2):1-2

Eidenshink J, Schwind B, Brewer K, Zhu Z, Quayle B, Howard S (2007) A project for monitoring trends in burn severity. Fire Ecol 3(1):3-21

Ettl GJ, Peterson DL (1995) Extreme climate and variation in tree growth: individualistic response in subalpine fir (Abies lasiocarpa). Glob Chang Biol 1:231-241

Flannigan MD, Stocks BJ, Wotton BM (2000) Climate change and forest fires. Sci Total Environ 262:221-229

Franklin J (2013) Species distribution models in conservation biogeography: developments and challenges. Divers Distrib 19:1217-1223

Garcia-Valdes R, Zavala MA, Araujo MB, Purves DW (2013) Chasing a moving target: projecting climate change-induced shifts in non-equilibrial tree species distributions. J Ecol 101:441-453

Gibson CE (2006) A northern Rocky Mountain polygon fire history: accuracy, limitations, strengths and recommended protocol of digital fire perimeter data. University of Idaho, Department of Forest Resources, Moscow, USA, Thesis 
Gibson CE, Morgan P (2009) Atlas of digital polygon fire extents for Idaho and western Montana (1889-2003). USDA Forest Service, Rocky Mountain Research Station, Fort Collins, Colorado, USA

Gibson J, Moisen G, Frescino T, Edwards TC (2014) Using publicly available forest inventory data in climate-based models of tree species distribution: examining effects of true versus altered location coordinates. Ecosystems 17:43-53

Gitlin AR, Sthultz CM, Bowker MA, Stumpf S, Paxton KL, Kennedy K, Munoz A, Bailey JK, Whitham TG (2006) Mortality gradients within and among dominant plant populations as barometers of ecosystem change during extreme drought. Conserv Biol 20:1477-1486

Gustafson EJ, Shinneman DJ (2015) Approaches to modeling landscape-scale drought-induced forest mortality. In: Perera AH, Sturtevant BR, Buse LJ (eds) Simulation Modeling of Forest Landscape Disturbances. Springer International Publishing, Switzerland, pp 45-71

Gustafson EJ, Shvidenko AZ, Sturtevant BR, Scheller RM (2010) Using landscape disturbance and succession models to support forest management. In: Li C, Lafortezza R, Chen J (eds) Landscape Ecology and Forest Management: Challenges and Solutions in a Change Globe. Springer International Publishing, Switzerland, pp 99-118

Haire S, McGarigal K (2010) Effects of landscape patterns of fire severity on regenerating ponderosa pine forests (Pinus ponderosa) in New Mexico and Arizona, USA. Landsc Ecol 25:1055-1069

Halofsky JE, Hemstromb MA, Conklin DR, Halofsky JS, Kerns BK, Bachelet D (2013) Assessing potential climate change effects on vegetation using a linked model approach. Ecol Model 266:131-143

Halofsky JS, Halofsky JE, Burcsu T, Hemstrom MA (2014) Dry forest resilience varies under simulated climate-management scenarios in a central Oregon, USA landscape. Ecol Appl 24:1908-1925

Hansen WD, Romme WH, Ba A, Turner MG (2016) Shifting ecological filters mediate postfire expansion of seedling aspen (Populus tremuloides) in Yellowstone. For Ecol Manag 362:218-230

Harvey BJ, Donato DC, Turner MG (2016) High and dry: post-fire tree seedling establishment in subalpine forests decreases with post-fire drought and large stand-replacing burn patches. Glob Ecol Biogeogr 25:655-669

Hawbaker TJ, Zhu Z (2012) Projected future wildland fires and emissions for the Western United States. In: Zhu Z, Reed BC (eds) Baseline and Projected Future Carbon Storage and Greenhouse-gas Fluxes in Ecosystems of the Western United States, vol 1797, US Geological Survey Professional Paper

He HS, Mladenoff DJ (1999) Spatially explicit and stochastic simulation of forest landscape fire disturbance and succession. Ecology 80:81-99

Heyerdahl EK, Morgan P, Riser JP (2008) Multi-season climate synchronized historical fires in dry forests (1650-1900), northern Rockies, USA. Ecology 89:705-716

Hutchinson GE (1957) Concluding remarks. Cold Spring Harb Symp Quant Biol 22:415-427

IPCC (2000) Emission Scenarios, A special report of IPCC working Group III. Published for the Intergovernmental Panel on Climate Change, Cambridge University Press, Cambridge, UK

Iverson LR, McKenzie D (2013) Tree-species range shifts in a changing climate: detecting, modeling, assisting. Landsc Ecol 28:879-889

Iverson LR, Prasad AM (1998) Predicting abundance of 80 tree species following climate change in the eastern United States. Ecol Monogr 68(4):465-485

Johnstone JF, McIntire EJB, Pedersen EJ, King G, Pisaric MJF (2010) A sensitive slope: estimating landscape patterns of forest resilience in a changing climate. Ecosphere 1(6):1-21

Kaufmann MR, Huckaby LS, Fornwalt PJ, Stoker JM, Romme WH (2003) Using tree recruitment patterns and fire history to guide restoration of an unlogged ponderosa pine/Douglas-fir landscape in the southern Rocky Mountains after a century of fire suppression. Forestry 76:231-241

Keane RE, Cary GJ, Flannigan MD, Parsons RA, Davies ID, King KJ, Li C, Bradstock RA, Gill M (2013) Exploring the role of fire, succession, climate, and weather on landscape dynamics using comparative modeling. Ecol Model 266:172-186

Kuparinen A, Savolainen O, Schurr FM (2010) Increased mortality can promote evolutionary adaptation of forest trees to climate change. For Ecol Manag 259:1003-1008

Landhäusser SM, Deshaies D, Lieffers VJ (2010) Disturbance facilitates rapid range expansion of aspen into higher elevations of the Rocky Mountains under a warming climate. J Biogeogr 37:68-76

Lenihan JM, Bachelet D, Neilson RP, Drapek R (2008) Simulated response of conterminous United States ecosystems to climate change at different levels of fire suppression, $\mathrm{CO} 2$ emission rate, and growth response to $\mathrm{CO} 2$. Glob Planet Chang 64:16-25
Lintz HE, McCune B, Gray AN, McCulloh KA (2011) Quantifying ecological thresholds from response surfaces. Ecol Model 222:427-436

Littell JS, Oneil EE, McKenzie D, Hicke JA, Lutz JA, Norheim RA, Elsner MM (2010) Forest ecosystems, disturbance, and climatic change in Washington State, USA. Clim Chang 102:129-158

Loehman RA, Clark JA, Keane RE (2010) Modeling effects of climate change and fire management on western white pine (Pinus monticola) in the northern Rocky Mountains, USA. Forests 2:832-860

Lotan JE, Critchfield WB (1990) Pinus contorta (Dougl. ex Loud). In: Burns RM, Honkala BH (eds) (technical coordinators) Silvics of North America, Vol 1 USDA Agriculture Handbook No 654, Washington, DC

Maguire KC, Nieto-Lugilde D, Fitzpatrick MC, Williams JW, Blois JL (2015) Modeling species and community responses to past, present, and future episodes of climatic and ecological change. Annu Rev Ecol Evol Syst 46:343-368

McCune B (2006) Nonparametric habitat models with automatic interactions. J Veg Sci 17:819-830

McKenzie D, Peterson DL, Littell JJ (2009) Global warming and stress complexes in forests of western North America. In: Bytnerowicz A, Arbaugh M, Riebau A, Andersen C (eds) Developments in Environmental Science, Volume 8. Elsevier, Philadephia, PA, USA

Michaelian M, Hogg EH, Hall R, Arsenault E (2011) Massive mortality of aspen following severe drought along the southern edge of the Canadian boreal forest. Glob Chang Biol 17:2084-2094

Mladenoff DJ, He HS (1999) Design, behavior and applications of LANDIS, an object-oriented model of forest landscape disturbance and succession. In: Mladenoff DJ, Baker WL (eds) Advances in Spatial Modeling of Forest Landscape Change: Approaches and Applications. Cambridge University Press, Cambridge, UK, pp 125-162

Morgan P, Parsons R (2001) Historical range of variability of forests of the Idaho Southern Batholith Ecosystem: final report to Boise Cascade Corporation, Boise, ID., On file at Nez Perce Forest Headquarters

Morgan P, Heyerdahl EK, Gibson CE (2008) Multi-season climate synchronized forest fires throughout the 20th century, northern Rockies, USA. Ecology 89:717-728

Moser B, Temperli C, Schneiter G, Wohlgemuth T (2010) Potential shift in tree species composition after interaction of fire and drought in the central Alps. Eur J For Res 129:625-633

Mote PW, Salathe EP (2010) Future climate in the Pacific Northwest. Clim Change: doi:10.1007/s10584-010-9848-z

Neilson RP, Pitelka LF, Solomon AM, Nathan R, Midgey GF, Fragoso JMV, Lischke $H$, Thompson K (2005) Forecasting regional to global plant migration in response to climate change. Bioscience 55(9):749-759

Oliver WW (1990) Spacing and shrub competition influence 20-year development of planted ponderosa pine. West J Appl For 5(3):79-82

Pearson RG, Dawson TP (2003) Predicting the impacts of climate change on the distribution of species: are bioclimate envelope models useful? Glob Ecol Biogeogr 12:361-371

Pierce JL, Meyer GA, Jull TAJ (2004) Fire-induced erosion and millennial-scale climate change in northern ponderosa pine forests. Nature 432:87-90

Rehfeldt GE (2006) A spline model of climate for the Western United States. In: General Technical Report. RMRS-GTR-165. U.S. Department of Agriculture, Forest Service, Rocky Mountain Research Station, Fort Collins, CO, p 21

Rehfeldt GE, Crookston NL, Warwell MV, Evans JS (2006) Empirical analyses of plant-climate relationships for the western United States. Int J Plant Sci 167(6):1123-1150

Rehfeldt GE, Ferguson DE, Crookston NL (2008) Quantifying the abundance of co-occurring conifers along inland Northwest (USA) climate gradients. Ecology 89(8):2127-2139

Rehfeldt GE, Crookston NL, Saenz-Romero C, Campbell EM (2012) North American vegetation model for land-use planning in a changing climate: a solution to large classification problems. Ecol Appl 22(1):119-141

Rehfeldt GE, Jaquish BC, López-Upton J, Sáenz-Romero C, St Clair JB, Leites LP, Joyce DG (2014) Comparative genetic responses to climate for the varieties of Pinus ponderosa and Pseudotsuga menziesii: realized climate niches. For Ecol Manag 324:126-137

Roccaforte JP, Fule PZ, Chancellor WW, Laughlin DC (2012) Woody debris and tree regeneration dynamics following severe wildfires in Arizona ponderosa pine forests. Can J For Res 42:593-604

Rollins MG (2009) LANDFIRE: a nationally consistent vegetation, wildland fire, and fuel assessment. Int J Wildland Fire 18:235-249

Savage M, Mast JN (2005) How resilient are southwestern ponderosa pine forests after crown fires? Can J For Res 35:967-977 
Savage M, Mast JN, Feddema JJ (2013) Double whammy: high-severity fire and drought in ponderosa pine forests of the Southwest. Can J For Res 43: $570-583$

Scheller RM, Mladenoff DJ (2007) A spatially interactive simulation of climate change, harvesting, wind, and tree species migration and projected changes to forest composition and biomass in northern Wisconsin, USA. Glob Chang Biol 11(2):307-321

Scheller RM, Mladenoff DJ (2008) Simulated effects of climate change, fragmentation, and inter-specific competition on tree species migration in northern Wisconsin, USA. Clim Res 36:191-202

Scheller RM, Domingo JB, Sturtevant BR, Williams JS, Rudy A, Gustafson EJ, Mladenoff DL (2007) Design, development, and application of LANDIS-II, a spatial landscape simulation model with flexible temporal and spatial resolution. Ecol Model 201:409-419

Schrag AM, Bunn AG, Graumlich LJ (2008) Influence of bioclimatic variables on treeline conifer distribution in the Greater Yellowstone Ecosystem: implications for species of conservation concern. J Biogeogr 35:698-710

Shaw JD, Steed BE, DeBlander LT (2005) Forest Inventory and Analysis (FIA) annual inventory answers the question: what is happening to pinyon-juniper woodlands? J For 103:280-285

Shinneman DJ, Cornett MW, Palik BJ (2010) Simulating restoration strategies for a southern boreal forest landscape with complex land ownership patterns. For Ecol Manag 259:446-458

Shinneman DJ, Means RE, Potter KM, Hipkins VD (2016) Exploring climate niches of ponderosa pine (Pinus Ponderosa Douglas ex Lawson) haplotypes in the western United States: implications for evolutionary history and conservation. PLOS ONE 11(3):e0151811. doi:10.1371/journal.pone.0151811

Snell R (2014) Simulating long-distance seed dispersal in a dynamic vegetation model. Glob Ecol Biogeogr 23:89-98

Sturtevant BR, Scheller RM, Miranda BR, Shinneman DJ, Syphard A (2009) Simulating dynamic and mixed-severity fire regimes: a process-based fire extension for LANDIS-II. Ecol Model 220:3380-3393

Sturtevant BR, Miranda BR, Shinneman DJ, Gustafson EJ, Wolter PT (2012) Comparing modern and presettlement forest dynamics of a subboreal wilderness—does spruce budworm enhance fire risk? Ecol Appl 22(4):1278-1296

Swab RM, Regan HM, Keith DA, Regan TJ, Ooi MKJ (2012) Niche models tell half the story: spatial context and life-history traits influence species responses to global change. J Biogeogr 39(7):1266-1277

Travis JMJ, Delgado M, Bocedi G, Baguette M, Bartoń K, Bonte D, Boulangeat I, Hodgson JA, Kubisch A, Penteriani V, Saastamoinen M, Stevens VM, Bullock JM (2013) Dispersal and species' responses to climate change. Oikos 122: $1532-1540$

Tucker CM, Rebelo AG, Manne LL (2012) Contribution of disturbance to distribution and abundance in a fire-adapted system. Ecography 35:348-355

Turner MG, Romme WH, Gardner RH, Hargrove WW (1997) Effects of fire size and pattern in early succession in Yellowstone National Park. Ecological Monographs 67:441-443

Valclavik T, Meentemeyer RK (2012) Equilibrium or not? Modelling potential distribution of invasive species in different stages of invasion. Divers Distrib 18:73-83

Vanderwel MC, Purves DW (2014) How do disturbances and environmental heterogeneity affect the pace of forest distribution shifts under climate change? Ecography 37:10-20

Westerling AL, Hidalgo HG, Cayan DR, Swetnam TW (2006) Warming and earlier spring increase western US forest wildfire activity. Science 313:940-943

Westerling AL, Turner MG, Smithwick EAH, Romme WH, Ryan MG (2011) Continued warming could transform Greater Yellowstone fire regimes by mid-21st century. Proc Natl Acad Sci 108(32):13165-13170

Whitlock CA, Briles CE, Fernandez MC, Gage J (2011) Holocene vegetation, fire and climate history of the Sawtooth Range, central Idaho, USA. Quat Res 75: 114-124

Woodward Fl (1987) Climate and plant distribution Cambridge. University Press, London

Woodward Fl, McKee IF (1999) Vegetation and climate. Environ Int 17:535-546

Xu C, Gertner GZ, Scheller RM (2009) Uncertainties in the response of a forest landscape to global climatic change. Glob Chang Biol 15:116-131

Yang J, Weisberg P, Shinneman DJ, Dilts TE, Earnst SL, Scheller RM (2015) Fire modulates climate change response of simulated aspen distribution across topoclimatic gradients in a semi-arid montane landscape. Landsc Ecol 30(6): 1055-1073

Zhu K, Woodall CW, Clark JS (2012) Failure to migrate: lack of tree range expansion in response to climate change. Glob Chang Biol 18:1042-1052

\section{Submit your manuscript to a SpringerOpen ${ }^{\circ}$ journal and benefit from:}

- Convenient online submission

- Rigorous peer review

- Immediate publication on acceptance

- Open access: articles freely available online

- High visibility within the field

- Retaining the copyright to your article

Submit your next manuscript at $\gg$ springeropen.com 